\title{
PROTEÇÃO RESPIRATÓRIA DO COMBATENTE DE INCÊNDIO FLORESTAL
}

Michel Aquino de Souza ${ }^{1}$

\begin{abstract}
RESUMO
A fumaça do incêndio florestal contém contaminantes que podem causar problemas respiratórios. Combatentes de incêndios florestais por todo o mundo estão se protegendo contra esse risco. Este trabalho apresenta uma revisão da literatura científica internacional e aponta possíveis soluções para proteção respiratória dos combatentes de incêndios florestais do Brasil. Entre os principais poluentes da fumaça estão: acroleína e formaldeído que irritam as mucosas, monóxido de carbono que pode ocasionar colapso, coma e morte; e material particulado que além de cardiopatias pode causar câncer pulmonar. As primeiras ações a serem implementadas a fim de evitar a intoxicação e patologias relacionadas aos contaminantes da fumaça são: a adoção de uma doutrina de proteção respiratória transmitida nas instruções operacionais; o uso de produtos de combate seguros quanto à toxicidade; e a adoção de táticas de posicionamento que evitem a exposição à fumaça. O uso de respiradores apropriados de qualidade associados a monitores de monóxido de carbono deve ser adotado no âmbito de um programa de proteção respiratória institucionalizado. Embora o mercado disponha de poucos respiradores desenvolvidos especificamente para o combatente de incêndios florestais, alguns outros podem ser utilizados com segurança pois atendem critérios técnicos de adequação. Em paralelo, alguns monitores não especificados para o combatente florestal podem servir para detecção e alarme evitando a exposição tóxica. Por conseguinte, a adoção dessa estratégia irá assegurar a saúde e a integridade física do combatente.
\end{abstract}

Palavras-chaves: Respirador; Monóxido; Câncer; Bombeiro; Máscara.

1 Biólogo, Mestre em Ciências Florestais, Combatente Florestal do CBMDF. Email: michel.pcif@gmail.com 


\title{
RESPIRATORY PROTECTION OF WILDFIRE FIGHTERS
}

\begin{abstract}
Smoke from forest fires contains contaminants that can cause breathing problems. Forest fire fighters around the world are protecting themselves against this risk. This work presents a review of the international scientific literature and points out possible solutions for the respiratory protection of forest fire fighters in Brazil. Among the main pollutants of smoke are: acrolein and formaldehyde that irritate the mucous membranes, carbon monoxide that can cause collapse, coma and death; and particulate matter that in addition to heart disease can cause lung cancer. The first actions to be implemented in order to avoid intoxication and pathologies related to smoke contaminants are: the adoption of a respiratory protection doctrine transmitted in the operating instructions; the use of toxic-safe combat products; and the adoption of positioning tactics that avoid exposure to smoke. The use of appropriate quality respirators associated with carbon monoxide monitors should be adopted as part of an institutionalized respiratory protection program. Although the market has few respirators developed specifically for the combatant of forest fires, some others can be used safely because they meet technical criteria of adequacy. In parallel, some monitors not specified for the forest fighter can be used for detection and alarm avoiding toxic exposure. Therefore, the adoption of this strategy will ensure the combatant's health and physical integrity.
\end{abstract}

Keywords: Respirator; Monoxide; Cancer; Fireman; Mask. 


\section{INTRODUÇÃO}

Os incêndios florestais liberam sim gases tóxicos. Como eles ocorrem em vegetação, é senso comum que eles não produzem gases tóxicos e, portanto, não oferecem perigo de toxicidade respiratória. Mas essa é uma impressão equivocada. Alguns contaminantes têm efeitos agudos como dor de cabeça e até desmaio, outros apresentam consequências crônicas como problemas cardíacos e câncer.

Além de naturalmente esses incêndios liberarem gases tóxicos, muitas vezes o combate se dá em áreas antropizadas: agrícolas com agroquímicos (fertilizantes e defensivos); industriais com rejeitos (subprodutos e sobras), militares com sobras de armas químicas, biológicas e eventualmente radioativas (AGER et al., 2019). Mesmo áreas urbanas com resíduos e lixos expõem o combatente aos mesmos gases perigosos dos incêndios estruturais urbanos.

O uso de Equipamento de Proteção Respiratória Autônomo (EPRA) é inconveniente ao trabalho de combate a incêndios florestais, pois tem um peso relativamente alto (cerca de $16 \mathrm{Kg}$ ) e baixa autonomia. A National Fire Protection Association (NFPA) em seu documento sobre a preparação já aponta para necessidade de uso de um sistema de proteção respiratória suficientemente efetivo para os combatentes florestais, alertando para inadequação do EPRA com restrição de mobilidade, além da necessidade de vários cilindros reserva na cena de grandes incêndios em ambientes remotos.

A exposição à fumaça a curto prazo com pequenas doses diárias nos incêndios florestais normalmente resulta em irritação nos olhos, tosse, depressão do sistema imune e declínios sazonais na função pulmonar que podem ser revertidos caso cesse a exposição. A exposição por vários dias ou semanas pode reduzir a capacidade de remover partículas das vias aéreas com tosse que pode levar a bronquite. (HVENEGAARD, 2012). Mas no longo prazo, Navarro et al., 2019, mostram que os combatentes florestais têm um 
risco aumentado de mortalidade: de $8 \%$ até $43 \%$ para câncer de pulmão (49 a 98 dias de combate anuais respectivamente) e de $16 \%$ a $30 \%$ de doenças cardiovasculares (respectivamente 5 a 25 anos de serviço de combate).

Na prevenção também há risco de intoxicação. Se a queima prescrita for realizada no início da estação seca, haverá maior emissão de gases potencialmente tóxicos. Há que se lembrar que o fogo sobre a vegetação não é homogêneo, ou seja, dependendo das condições climáticas e do tipo de vegetação (fitofisionomia, bioma, hábitos, espécies), os gases emitidos podem variar. Do mesmo modo, a intoxicação depende da exposição e, portanto, da distância até as chamas pois os gases estão mais concentrados onde são gerados, assim os mais afetados são os combatentes. (RIBEIRO e ASSUNÇÃO, 2002).

O combate a incêndio florestal está associado à diminuição da função pulmonar, aumento da inflamação sistêmica e pulmonar, além sintomas respiratórios. Há que se ressaltar que a sintomatologia e as possíveis patologias não serão experimentadas por todos os bombeiros. Naturalmente, as condições de saúde principalmente relacionadas ao sistema cardiopulmonar, idade e compleição física, indicarão a maior susceptibilidade ou resiliência de cada indivíduo. (YOUSSOUF et al, 2014). Porém a exposição prolongada e recorrente, afeta a capacidade homeostática de restauração. Portanto, é necessário um Equipamento de Proteção Respiratória com filtros capazes de reter os materiais particulados e os gases orgânicos, especialmente os gases tóxicos, para salvaguarda da saúde dos combatentes de incêndios florestais.

O Objetivo deste trabalho é fazer uma revisão na literatura científica sobre o uso de equipamento de proteção respiratória (EPI/EPR) no combate a incêndios florestais e propor soluções.

A Metodologia utilizada no desenvolvimento deste trabalho foi a revisão de literatura nacional e internacional não só em base de dados acadêmicos, mas também em informações do mercado e experiências compartilhadas de vários combatentes e pesquisadores de incêndios florestais. Foi realizado ensaio de monitoramento de CO e MP. 


\section{RESULTADOS e DISCUSSÃO}

\subsection{Exposição à fumaça}

Outros riscos estão associados ao combate, além dos contaminantes da fumaça. Carballo-Leyenda et al., 2019, estudando a exposição dos bombeiros florestais espanhóis em incêndios reais, encontraram picos absolutos de fluxo de calor que atingiram valores de $10.000 \mathrm{~W} \cdot \mathrm{m}^{-2}$ e temperaturas de $78,0^{\circ} \pm 8,9^{\circ}$ $\mathrm{C}$ em combate direto, o que significou uma exposição perigosa com risco de queimaduras.

Buschinelli, 2020, referencia que os gases e vapores são os maiores perigos na exposição ocupacional pois têm maior potencial de absorção respiratória e cutânea pelo trabalhador, bem como os sólidos aerodispersóides. Oliveira Alves et al., 2017, apontam a queima de biomassa como fonte de compostos cancerígenos que se espalham a partir da pluma a grandes distâncias. Um dos principais componentes cancerígenos é o material particulado que pode penetrar nos alvéolos pulmonares, passar para o sangue e se acumular em outros órgãos.

Urbanski et al., 2008, referencia os incêndios florestais como a principal fonte de poluição do ar. Entre outros gases, ele aponta para as altas concentrações de Monóxido de Carbono (CO), Ácido Cianídrico, Acetaldeído, Óxido Nítrico. Esses, segundo os limites de tolerância da Norma Regulamentadora n. 15- que versa sobre Atividades e Operações Insalubres, do Ministério do Trabalho, apresentam graus máximos de insalubridade. Os dados da Tabela 1 indicam os contaminantes liberados durante incêndios em florestas extratropicais, como as que ocorrem no sul do Brasil. 


\section{Revista FLAMMAE}

Revista Científica do Corpo de Bombeiros Militar de Pernambuco

Artigo Publicado no Vol.06 N.17 - Edição Jul a Dez 2020 - ISSN 2359-4829

Versão on-line disponível em: http://www.revistaflammae.com

Tabela 1 - Principais contaminantes e suas proporções em relação ao $\mathrm{CO}$, para florestas extratropicais. ${ }^{*}$ SCV- Sistema Cardio Vascular, SNC- Sistema Nervoso Central. ${ }^{* *}$ Outras

fontes. As cores representam nível de alerta e perigo.

\begin{tabular}{|l|r|l|l|}
\hline Contaminante & $\begin{array}{l}\text { Vezes acima } \\
\text { do aceitável }\end{array}$ & $\begin{array}{l}\text { Relação } \\
\text { com Co }\end{array}$ & Efeitos críticos e órgãos/ sistemas afetados \\
\hline Formaldeído & 6111 & 1,5 & Irritação, alergia, câncer \\
\hline Monóxido de Carbono & 4005 & 1,0 & Anóxia, SCV, SNC, reprodução \\
\hline Material Particulado 2,5 & 4333 & 1,08 & Inflamação, câncer ** \\
\hline Acroleína & 1200 & 0,3 & Irritação, edema pulmonar \\
\hline Benzeno & 307 & 0,077 & Câncer \\
\hline Dióxido de carbono & 174 & 0,044 & Asfixia \\
\hline NO & 536 & 0,134 & Irritação, edema pulmonar, reprodução, sangue, SNC \\
\hline $\mathrm{N}_{2} \mathrm{O}$ & 3 & 0,001 & SNC, hematológico, embrionário fetal \\
\hline Benzo(a)pireno (HPA) & 125 & 0,031 & Câncer \\
\hline Amônia & 80 & 0,020 & Irritação \\
\hline Furfural & 59 & 0,015 & Irritação \\
\hline Acetaldeído & 11 & 0,0034 & Irritação \\
\hline Butadieno & 14 & 0,0034 & Câncer \\
\hline Metano & 7 & 0,0018 & Depressão do SNC, alergia cardíaca \\
\hline Metanol & 8 & 0,0019 & Neuropatia, visão, SNC \\
\hline Estireno & 2 & 0,0004 & Neurotoxicidade, irritação, SNC \\
\hline Acetonitrila & 6 & 0,0014 & Pele, pulmões \\
\hline Propionaldeído & 3 & 0,00074 & Irritação nasal \\
\hline Tolueno & 2 & 0,00053 & SNC \\
\hline Outros & Abaixo do & $\begin{array}{l}\text { Muito } \\
\text { baixa }\end{array}$ & SNC, pele, irritação, rins, reprodução, sangue, \\
\hline
\end{tabular}

Fonte: Adaptado de AUSTIN, 2008.

Os limites de exposição ocupacional (Tabela 2) são estabelecidos pela média da concentração de exposição a que o trabalhador está submetido em $8 \mathrm{~h}$ por dia, 40h por semana. Há também o limite de exposição de curto prazo calculado pela média ponderada das concentrações durante 15 minutos, que não pode ser excedido a qualquer momento durante o trabalho. $O$ limite de exposição que nunca pode ser excedido é considerado Atmosfera Imediatamente Perigosa para Vida e Saúde- AIPVS. (NIOSH, 2013). Limitar a exposição ocupacional do monóxido de carbono pode não proteger os bombeiros florestais da superexposição a outras substâncias como MP fino e ultrafino, formaldeído, benzo[a]pireno e acroleína. Como no caso de 35 ppm de monóxido de carbono, leva a superexposição ao HPA (Hidrocarboneto Policíclico Aromático- benzo [a] pireno). (AUSTIN, 2008). 
Revista Científica do Corpo de Bombeiros Militar de Pernambuco

Artigo Publicado no Vol.06 N.17 - Edição Jul a Dez 2020 - ISSN 2359-4829

Versão on-line disponível em: http://www.revistaflammae.com

Tabela 2 - Limites de exposição ocupacional de contaminantes tóxicos da fumaça. ${ }^{*}$ Depende da concentração e tempo de exposição. AIPVS- Atmosfera Imediatamente Perigosa para Vida

e Saúde.

\begin{tabular}{l|l|l|l|l|l}
\hline Componente & $\underline{\text { Unid. }}$ & $\underline{8 \mathrm{~h}}$ & $\underline{15 \mathrm{~min}}$ & $\underline{\text { AIPVS }}$ & $\begin{array}{l}\text { Complicaç̃es ao se exceder o limite e } \\
\text { características* }\end{array}$ \\
\hline Acroleína & $\mathrm{ppm}$ & 0,1 & 0,3 & 2 & $\begin{array}{l}\text { Irritação dos olhos e do trato respiratório } \\
\text { superior. Edema e enfisema pulmonar. } \\
\text { Irritação da pele. Queima e volatiliza fácil. } \\
10 \text { ppm pode ser letal em curto tempo. }\end{array}$ \\
\hline Benzeno & $\mathrm{ppm}$ & 1 & 5 & 500 & $\begin{array}{l}\text { Leucemia. Carcinogênese. Absorção pela } \\
\text { pele. }\end{array}$ \\
\hline $\begin{array}{l}\text { Monóxido de } \\
\text { Carbono }\end{array}$ & $\mathrm{ppm}$ & 35 & 200 & 1200 & $\begin{array}{l}\text { Mudanças adversas neurocomporta- } \\
\text { mentais e na capacidade cardiovascular. }\end{array}$ \\
\hline Formaldeído & $\mathrm{ppm}$ & - & - & 20 & $\begin{array}{l}\text { Irritação dos olhos e do trato respiratório } \\
\text { superior. Alérgeno. Tolerável no máximo } \\
\text { até 5 ppm. }\end{array}$ \\
\hline Benzopireno & $\mathrm{mg} \cdot \mathrm{m}^{-3}$ & 0,005 & - & - & \multicolumn{3}{c}{ Câncer } \\
\hline
\end{tabular}

Reinhardt e Ottmar, 2004, observaram que os bombeiros se expõem a níveis significativos de monóxido de carbono, formaldeído, acroleína e material particulado nos combates a incêndios florestais e até a benzeno principalmente quando utilizam queimadores e motores a combustão. Eles observaram que a maioria dos poluentes estavam razoavelmente correlacionados com 0 monóxido de carbono, indicando o uso de detectores de CO para prevenção da exposição a altas concentrações dos diversos poluentes.

Bombeiros florestais californianos chegam a perder $10 \%$ de sua capacidade respiratória em uma temporada de combate, podendo levar a asma e câncer, principalmente a partir de combustíveis mais verdes. Eles relataram ausência de dores de cabeça e enjoos quando utilizaram uma máscara full face para o combate (CONE, 1992).

Os pesquisadores do Projeto Prometheu (Chamada 33/2018 CNPq Prevfogo/lbama) já observaram concentrações instantâneas de 8,3 a 20,2 ppm de $\mathrm{CO}$ e Material Particulado Fino $\left(\mathrm{MP}_{2,5}\right)$ acima de 521 ppm e $\mathrm{MP}_{10}$ acima de 973 ppm em combates relativamente leves conforme figura abaixo (Figura 1). 
Revista Científica do Corpo de Bombeiros Militar de Pernambuco

Artigo Publicado no Vol.06 N.17 - Edição Jul a Dez 2020 - ISSN 2359-4829

Versão on-line disponível em: http://www.revistaflammae.com

Figura 1 - Levantamento da Exposição ao $\mathrm{MP}_{2,5}$ (1 ${ }^{\mathrm{a}}$ imagem $)$ e $\mathrm{CO}\left(2^{\mathrm{a}}\right.$ imagem $)$ em um combate real a incêndio florestal em Brasília. O combatente percorreu a linha de fogo durante $O$ período de $2 \mathrm{~h}$ com bomba costal equipada com o sistema eletrônico embarcado OBÁ. Nessa ocasião, foi observado uma perda de massa corporal de $2 \mathrm{Kg}$ no combatente associado a um aumento na glicemia.
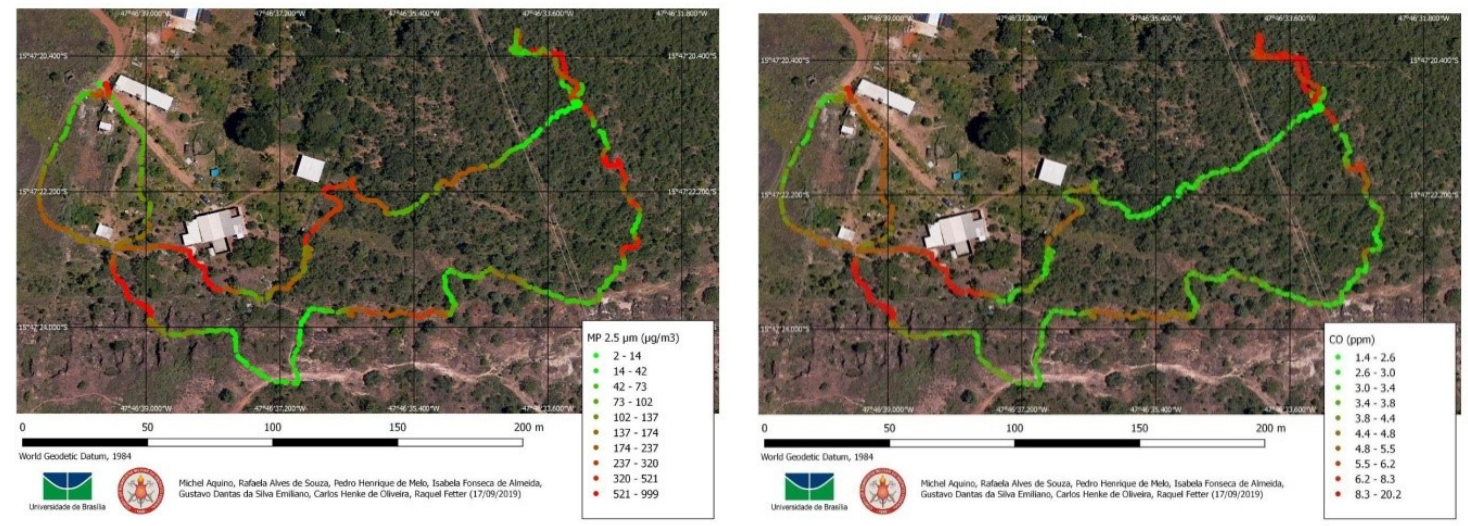

\subsection{Contaminantes perigosos e riscos à saúde}

A fumaça de incêndio florestal possui contaminantes que podem causar danos à saúde do combatente e afetar sua capacidade operacional. Os contaminantes podem ser classificados em aerodispersóides, gases e vapores.

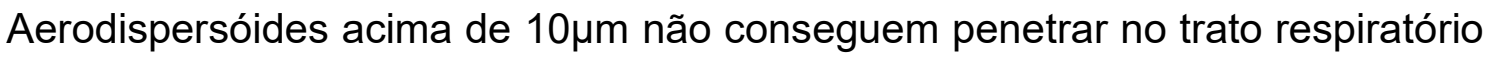
pois são detidas pelas mucosas e pelos do nariz. Partículas com diâmetro inferior a $10 \mu \mathrm{m}$ são respiráveis e, partículas inferiores a $3 \mu \mathrm{m}$ são depositadas nos alvéolos pulmonares. Os aerodispersóides podem ser poeiras, fumos, fumaça, névoas, neblinas e radionuclídeos. (TAVARES, 2009).

Austin, 2008, apresenta uma alta correlação positiva, estatisticamente significativa, entre as concentrações de $\mathrm{CO}$ e as partículas respiráveis (MP $\leq$ 3,5 $\mu \mathrm{m}$ ), aldeídos, benzeno, formaldeído e acroleína na fumaça dos incêndios florestais para exposição pessoal média ponderada no tempo.

A exposição à fumaça (de incêndios florestais e queima de resíduos agrícolas) está correlacionada a sintomas cardiorrespiratórios em termos de visitas às urgências e internações. Estudos apontam para média de 339.000 mortes no mundo anualmente associadas à exposição à fumaça de incêndios florestais. De acordo com o relatório de fatalidade de bombeiros de 2010 da US 
Fire Administration, a morte súbita cardíaca é responsável por $49 \%$ do total de mortes de bombeiros no trabalho. (YOUSSOUF et al, 2014).

Ranzani et al., 2019, associou as altas concentrações de exposição ao material particulado fino de indianos ao aumento na espessura da carótida como fator de risco para infarto do miocárdio. Já em 2020, Ranzani associou a baixa densidade óssea causadora da osteoporose à alta exposição ao $\mathrm{MP}_{2,5}$ provavelmente em razão do estresse oxidativo e inflamações causadas pelos poluentes.

Bombeiros californianos já tem diversos tipos de câncer reconhecidos como presuntivos da atividade florestal. Eles apresentaram leucemia, câncer testicular, câncer de pulmão, câncer no cérebro, câncer de bexiga, câncer de ureter, câncer colorretal e linfoma não-Hodgkins. (FAM/USFS, 2013). O risco relativo de mortalidade dos bombeiros para câncer de pulmão, doença isquêmica do coração e doença cardiovascular após uma carreira de 10 anos teria um aumento de 22 a $24 \%$ na mortalidade por essas doenças, em comparação com uma pessoa sem exposição à fumaça. Após 20 anos, o risco é de 25 a 39\%. (GABBERT, 2018)

Ao se combater o incêndio com água, retardante ou espuma, há que se considerar uma mudança na composição dos gases, possivelmente com um acréscimo de substâncias que compõem a fumaça. Por conseguinte, um aumento na quantidade de vapor de água nos gases desprendidos da combustão. Segundo Gabbert, 2018, os produtos químicos intermediários provenientes da queima de biomassa podem causar carcinogênese broncopulmonar, fibrogênese, lesão pulmonar, dificuldade respiratória, doença pulmonar obstrutiva crônica (DPOC) e inflamação. Nesse sentido, os Retardantes de chama bromados estão associados a casos de câncer em bombeiros. (Mayer et al., 2019).

A Gerência de Incêndio e Aviação do Serviço Florestal dos Estados Unidos (FAM/USFS, 2013) não avaliou se a fumaça da vegetação queimada próxima dos retardantes de longo tempo apresentam efeitos sobre a saúde respiratória. Entretanto, eles indicaram baixo risco cancerígeno se 0 manipulador do produto utilizar máscara facial com filtro. O Instituto Nacional de Ciências da Saúde Ambiental do Departamento de Saúde e Serviços 
Humanos dos Estados Unidos (NIEHS/DHHS, 2014) orienta que os retardantes podem persistir no ambiente por muito tempo após a aplicação e que alguns podem ter ingredientes cancerígenos. Se houver gases que irritam as mucosas e poeiras com amianto ou gases da queima de retardantes, eles indicam o uso de uma máscara de face completa com filtros P100. Os cartuchos dos respiradores devem ser substituídos caso haja dificuldade respiratória ou percepção de vapores orgânicos.

A perda da capacidade física dos combatentes de incêndios florestais se deve a sensibilização respiratória a alérgenos, material particulado e à fumaça. Isso se expressa na diminuição do consumo máximo de oxigênio $\left(\mathrm{VO}_{2}\right.$ máx), que a partir dos 30 anos de idade, que reduz cerca de $10 \%$ a cada 10 anos aumentando o risco de doenças cardiovasculares e respiratórias. (TARÍN, 2013). O desgaste durante o combate a incêndios florestais, indicado pelo índice de deformação fisiológica e índice cumulativo de deformação térmica, é bem maior no ataque direto, (RODRÍGUEZ-MARROYO, 2011) portanto, é indicado $\mathrm{o}$ ataque misto ou indireto para locais de incêndios em que as chamas são incombatíveis. Leman, 2019, relata que na fumaça encontram-se organismos extremófilos, arqueas, bactérias, fungos, e vírus. Esses microrganismos podem estar relacionados ao desenvolvimento de alergias e doenças nos combatentes florestais.

Alencar, 2018, coletou dados de Material Particulado e Monóxido de Carbono durante translado e queima prescrita por brigadistas florestais em atividades na Amazônia. Ela encontrou concentrações de CO e MP superiores ao estabelecido nas normas para o brigadista utilizador do pinga fogo. Considerando os riscos aos quais os combatentes de incêndios florestais estão expostos, entre os quais ataques cardíacos e acidentes vasculares encefálicos, Alencar, 2018, recomenda a implementação de revezamento das funções durante o combate, de avaliação de aptidão física, exames médicos periódicos inclusive avaliações pós combate.

\subsubsection{Material Particulado}

$O \mathrm{MP}_{2,5}$ é proveniente da queima de combustíveis florestais e leva compostos orgânicos, partículas de carvão, metais, e pode carrear gases tóxicos, toxinas, vírus e bactérias (HACON, 2019). Wu et al., 2020, estudando a 
relação entre a poluição atmosférica e a COVID-19 nos EUA, observa grande aumento de mortalidade por COVID-19 depois de incremento na exposição de longo prazo ao $\mathrm{MP}_{2,5}$.

Os Materiais Particulados (MP) são partículas em suspensão no ar que podem ser classificados em inalável (diâmetro aerodinâmico mediano igual a $100 \mu \mathrm{m}$ ) ou respirável (diâmetro aerodinâmico médio $\leq 4 \mu \mathrm{m}$ ). O MP respirável pode chegar a região alveolar transportando tóxicos adsorvidos e condensados para os pulmões onde pode se acumular causando câncer. O MP pode conter sílica cristalina causadora de silicose. $\mathrm{MP}_{10}$ apresenta diâmetro aerodinâmico equivalente de corte de $10 \mu \mathrm{m}$ e $\circ \mathrm{MP}_{2,5}$ tem diâmetro de 2,5 um.(CONE, 1992; AUSTIN, 2008; GABBERT, 2018). O material particulado (de 5 a $30 \mu \mathrm{m})$ fica retido e alcança até a traqueia, já o MP fino $(<2,5 \mu \mathrm{m})$ chega até os alvéolos com meia-vida que pode chegar a anos e é o que mais afeta 0 sistema respiratório.

$O \mathrm{MP}<10 \mu \mathrm{m}$ pode penetrar nas regiões alveolares do pulmão, atravessar a membrana plasmática, cair na corrente sanguínea e se acumular em outros tecidos. (DE OLIVEIRA ALVES et al., 2017). Foram associados ao acréscimo de MP no ar, $13 \%$ de aumento nas internações por doença pulmonar obstrutiva crônica, e $11 \%$ de aumento no risco de internação por insuficiência cardíaca congestiva após incêndios. A exposição à fumaça leva a inflamação sistêmica e pulmonar, especialmente em bombeiros. (YOUSSOUF et al., 2014). Alencar, 2018, observou picos de exposição ao $\mathrm{MP}_{2,5}$ de até 640,5 $\mu \mathrm{g} / \mathrm{m}^{3}$ em incêndios no Brasil.

As partículas ultrafinas são as que quando respiradas alcançam os tecidos pulmonares, podem escapar do envolvimento de macrófagos, penetrar no interstício alveolar e acabar translocadas para órgãos extrapulmonares como o fígado e o cérebro. Elas servem como veículo para transportar gases tóxicos adsorvidos e vapores na região de troca gasosa do pulmão. Portanto, a exposição a partículas respiráveis não classificadas de outra forma deve ser limitada a um período de 8 horas e concentração média ponderada no tempo 
de $3 \mathrm{mg} / \mathrm{m}^{3}$. (AUSTIN, 2008). As exposições a esses contaminantes devem ser mantidas abaixo de $10 \mathrm{mg} / \mathrm{m}^{3}$. (HACON, 2019). O limite de exposição para material particulado em geral é de 35 a $80 \mu \mathrm{g} / \mathrm{m}^{3}$. (ALENCAR, 2018).

Os combatentes florestais em Minaçú, Goiás, ainda têm que ter outra preocupação quanto a exposição respiratória, o amianto cancerígeno (LEMOS, 2019). Recentemente foi reativada a fabricação de peças com essa fibra mineral. Em incêndios de vegetação contaminada por asbestos, $5 \%$ suspende com a fumaça e $95 \%$ permanecem nas cinzas. Após um combate como esse, todo material empregado na operação deve passar por descontaminação com até 3 lavagens (OUELLET, 2018), pois é considerado como produto perigoso (NIEHS/DHHS, 2014).

\subsubsection{Monóxido de carbono}

Os incêndios geram monóxido de carbono (CO) que é um gás inodoro tóxico, e sua intoxicação inicial é assintomática. Mas depois, ele vai se ligar com a hemoglobina da hemácia impedindo o transporte do oxigênio e formando a carboxihemoglobina que condena a hemácia a morte. Isso pode levar a confusão mental, dores de cabeça, náusea, irritação, fadiga, desmaio, inconsciência, asfixia com movimentos respiratórios preservados, e até ao óbito. Esses sinais e sintomas podem indicar alta concentração de monóxido de carbono no ambiente que deve ser evacuado se não dispor de proteção respiratória adequada. (BYRD, 2019).

O monóxido de carbono além de aumentar o ritmo cardíaco e respiratório, afeta o sistema nervoso central. Geralmente, ele só pode ser retido em filtros específicos com rápida saturação, ou seja, os filtros mais simples só podem proteger o combatente por pouco tempo. (CONE, 1992). Trabalhar com equipamentos a combustão (motosserra, soprador, moto-bomba, roçadeira, gerador) eleva a concentração de $\mathrm{CO}$, aumentando o risco de exposição e intoxicação. (NIEHS/DHHS, 2014).

Hodgson et al., 2018, estudando a emissão de gases dos incêndios florestais nas plumas, observou que os incêndios florestais no cerrado emitiram em média $74 \mathrm{~g}$ de $\mathrm{CO}$ por $\mathrm{Kg}$ de combustível seco queimado. Na floresta 
amazônica as emissões chegaram a $237 \mathrm{~g} \cdot \mathrm{kg}^{-1}$, e em incêndios subterrâneos $291 \mathrm{~g} \cdot \mathrm{kg}^{-1}$. A eficiência da combustão no cerrado chegou a $97 \%$, enquanto na floresta tropical ficou em $74 \%$. Isso demonstra que o combatente florestal brasileiro está exposto a altas concentrações de CO principalmente em incêndios subterrâneos. Durante as operações de rescaldo, as concentrações de $\mathrm{CO}$ no ar podem ser ainda mais altas característica das combustões lentas (SOUZA, 2011). Portanto, em todas as atividades de prevenção e combate, deve-se monitorar a concentração de CO (NIEHS/DHHS, 2014).

O nível de carboxihemoglobina depende da pré-inalação (fumo, poluição, serviços anteriores), da taxa de ventilação relacionada à carga de trabalho, da duração da exposição e da concentração de CO na atmosfera. Durante o combate, ele pode aumentar em média, 0,7\% por hora nos bombeiros. As maiores concentrações de $\mathrm{CO}$ ocorrem em incêndios subterrâneos e durante o rescaldo. Geralmente, os bombeiros não se expõem a altas concentrações do $\mathrm{CO}$, mas isso pode ocorrer eventualmente, até na viatura durante o translado das equipes. (SOUZA, 2011; YOUSSOUF et al, 2014).

CARBALLO et al., 2010, encontraram exposição média ao monóxido de carbono menores que $23 \mathrm{ppm}$ em combate a incêndios florestais. Eles consideram estar dentro dos limites estabelecidos pelas autoridades de saúde espanholas. Alencar, 2018, observou picos de exposição ao CO de 62,2 ppm em incêndios de Roraima. Ela encontrou concentração de CO média de 11 ppm durante uma jornada média de 2,6h e pico de $\mathrm{CO}$ de 200 ppm mesmo com ventos de $1,76 \mathrm{~m} . \mathrm{s}^{-1} \mathrm{em}$ média, consequentemente superando a média recomendada pelo CONAMA 03/1990 que para o CO é 9 ppm em 8 h e 35 ppm em $1 \mathrm{~h}$.

Isso alerta para o fato de que sem a devida proteção as jornadas de efetivo combate devem ser curtas sob pena de exposição além dos limites estabelecidos, especialmente em casos de incêndios onde o fogo se alastra livremente. Se o $\mathrm{CO}$ estiver em altas concentrações os demais gases tóxicos também estarão (GABBERT, 2018). Desse modo, a detecção de CO é um bom indicador de toxicidade do ar para o combatente caso disponha do monitor de co. 
Revista Científica do Corpo de Bombeiros Militar de Pernambuco

Artigo Publicado no Vol.06 N.17 - Edição Jul a Dez 2020 - ISSN 2359-4829

Versão on-line disponível em: http://www.revistaflammae.com

Para avaliação visual do perigo, Austin, 2008, observou as seguintes condições. Na fumaça média, em que é possível ver a $100 \mathrm{~m}$ de distância, havia $30 \mathrm{ppm}$ de CO, 0,15 ppm de formaldeído e $3 \mathrm{mg} / \mathrm{m}^{3}$ de MP respirável. $\mathrm{Na}$ fumaça densa, através qual é possível ver apenas vultos a 100m de distância, houve previsão de $44 \mathrm{ppm}$ de $\mathrm{CO}, 0,20 \mathrm{ppm}$ de formaldeído e $5 \mathrm{mg} / \mathrm{m}^{3}$ de MP respirável, mas as medições indicaram de 3 a 5 vezes mais. Já na fumaça muito densa houve previsão de $58 \mathrm{ppm}$ de CO, 0,30 ppm de formaldeído e 6 $\mathrm{mg} / \mathrm{m}^{3}$ de MP respirável, mas as medições indicaram de 3 a 5 vezes mais. Neste caso, não é possível ver nada a $100 \mathrm{~m}$ de distância. A tabela 3 apresenta os sintomas que o combatente pode ter se estiver exposto ao $\mathrm{CO}$.

Tabela 3. Sinais e sintomas relacionados a Carboxihemoglobina $(\mathrm{COHb})$ em função do limite de $\mathrm{CO}$ atmosférico. Podem ser causados por outros gases e aparecer em níveis mais baixos de $\mathrm{COHb}$ durante o exercício, quando o corpo tem uma demanda maior por oxigênio. Adaptado

de Austin, 2008; e Souza, 2011. Alguns valores estimados por regressão.

\begin{tabular}{l|l|l}
$\begin{array}{l}\text { CO } \\
(\mathbf{p p m})\end{array}$ & $\begin{array}{l}\% \\
\text { COHb }\end{array}$ & \multicolumn{1}{c}{ Sinais e sintomas } \\
\hline 15 & $<3$ & Sem sintomas. \\
\hline 30 & $3-6$ & Capacidade de exercício levemente reduzida (5-7\%). \\
\hline 65 & $4-17$ & $\begin{array}{l}\text { Tempo de exercício reduzido em homens jovens e saudáveis durante exercícios } \\
\text { extenuantes. Confusão. Diminuição da percepção visual, da destreza manual, da } \\
\text { capacidade de aprender ou do desempenho em tarefas como dirigir. Dificuldade } \\
\text { respiratória em esforço vigoroso, aperto na testa, dilatação dos vasos cutâneos. }\end{array}$ \\
\hline 120 & $10-20$ & Aperto na testa, leve dor de cabeça e dilatação dos vasos (têmpora latejando). \\
\hline 130 & $16-20$ & Dor de cabeça, visão anormal, dificuldade respiratória em esforço moderado. \\
\hline 230 & $20-30$ & $\begin{array}{l}\text { Dor de cabeça e palpitações nas têmporas, fadiga fácil, irritação, distúrbio de } \\
\text { julgamento, tontura, visão turva. }\end{array}$ \\
\hline 350 & $30-40$ & $\begin{array}{l}\text { Dor de cabeça severa, fraqueza, tontura, confusão, visão turva, náusea, vômito, } \\
\text { colapso, síncope. }\end{array}$ \\
\hline 520 & $40-50$ & $\begin{array}{l}\text { Dor de cabeça severa, confusão, desmaio no esforço, pulso e frequência respiratória } \\
\text { aumentados, colapso. }\end{array}$ \\
\hline 780 & $50-60$ & $\begin{array}{l}\text { Aumento da frequência respiratória e de pulso, coma, convulsões intermitentes e } \\
\text { respiração cíclica irregular, possível morte. }\end{array}$ \\
\hline 1220 & $60-70$ & Coma, convulsões intermitentes, depressão cardio-respiratória, letal se não tratar. \\
\hline 1940 & $70-80$ & Pulso fraco, respiração lenta, insuficiência respiratória e morte em algumas horas. \\
\hline 3000 & $80-90$ & Morte em menos de uma hora. \\
\hline 3800 & $>90$ & Morte em alguns minutos. \\
\hline
\end{tabular}

Souza, 2011, aferindo a carboxihemoglobina com equipamento pulso CO oxímetro antes e depois do serviço de combate no mês de julho no Distrito Federal, demonstrou que $3 \%$ combatentes de incêndios florestais apresentaram variação nos níveis de $\mathrm{COHb}$ entre $5 \%$ e $10 \%$. O limite 
considerado normal para $\mathrm{COHb}$ é de $3 \%$. Souza, 2011, recomenda o monitoramento rotineiro da $\mathrm{COHb}$ nos bombeiros combatentes de incêndios florestais, tratando-os com oxigenoterapia caso o $\mathrm{COHb}$ esteja superior a $5 \% \mathrm{e}$ caso esteja maior que $15 \%$, o militar deverá ser transportado ao hospital. Souza, 2011, recomenda ainda que o uso de proteção respiratória deve estar associado ao monitoramento do $\mathrm{CO}$, sob pena de limitar o uso de máscaras devido a possibilidade de intoxicação por $\mathrm{CO}$.

Caso haja uma exposição ao $\mathrm{CO}$, o combatente deve obter atendimento conforme o percentual de Carboxi Hemoglobina $(\mathrm{COHb})$ que vai desde $\mathrm{O}$ afastamento da fumaça até atendimento médico emergencial em câmaras hiperbáricas. Caso seja fumante, a COHb pode ficar acima de $10 \%$, mesmo sem exposição à fumaça. Se a saturação de CO estiver entre 3 e $12 \%$ e apresentar sintomas de intoxicação, o tratamento indicado é o transporte para hospital com oxigenação saturada à $100 \%$. Neste caso, se não apresentar sintomas, sugere-se o uso de oxigenoterapia. Se SpCO for maior que $12 \%$, deve-se fazer o transporte com oxigenação saturada à 100\%. Caso haja, comprometimento neurológico evidenciado pela confusão mental ou perda de consciência ou saturação de $\mathrm{CO}>25 \%$, o paciente deve ser transportado com oxigenação à $100 \%$ ao hospital preferencialmente que disponha de Câmara Hiperbárica. (SOUZA, 2011).

\subsubsection{Hidrocarbonetos Policíclicos Aromáticos}

A pirólise e pirossíntese nos incêndios florestais geram Hidrocarbonetos Policíclicos Aromáticos (HPA), Benzeno e Reteno. Os HPAs são formados por anéis de benzeno. Eles são lipossolúveis e facilmente atravessam as membranas celulares sendo absorvidos pela pele, pulmões e estômago se acumulando em tecidos adiposos. Eles causam hepatopatia, irritação nas mucosas, asma e inflamação pulmonar por meio da autogafia, apoptose e necrose das células alveolares. Causam ainda genotoxicidade que se dá por alquilação das bases do DNA e danos oxidativos no DNA induzindo mutações cancerígenas. Na fumaça encontra-se principalmente o HPA benzo(a)pireno, também no alcatrão de carvão e no escapamento de motores a diesel. A exposição deve ser a menor possível a fim de evitar níveis prejudiciais à saúde. (AUSTIN, 2008; OLIVEIRA ALVES et al., 2017; BUSCHINELLI, 2020). 
O Benzeno isolado pode causar dores de cabeça, tontura, náusea, confusão e irritação do trato respiratório. A exposição prolongada pode sobrecarregar a capacidade de reparar danos aos genes e ao DNA. (GABBERT, 2018). O $\mathrm{MP}_{10}$ carreia uma série de HPAs que são os responsáveis por sua toxicidade e carcinogenicidade entre eles o Reteno. $O$ reteno (metil isopropil fenantreno) é um contaminante da fumaça de incêndios florestais que pode causar inflamação, danos ao DNA e morte das células alveolares pulmonares que se for elevada pode levar a dificuldades respiratórias e enfisema pulmonar, e até câncer de pulmão. (OLIVEIRA ALVES et al., 2017).

Vicente et al., 2017, encontraram grande concentração de Reteno (a maior entre os hidrocarbonetos policíclicos aromáticos) nas plumas de incêndios florestais portugueses. Peixoto et al., 2019, observaram que o reteno é o HPA mais abundante na queima de biomassa (principalmente folhas resinosas e madeira) e promove o estresse oxidativo, contribui para instabilidade genômica e favorece a necrose das células pulmonares (ALVES, 2014).

\subsubsection{Acroleína}

A Acroleína aumenta a possibilidade de infecções respiratórias, além de irritar o nariz, garganta e pulmões, bem como irritação respiratória crônica e perda permanente da função pulmonar se a exposição ocorrer por muitos anos (GABBERT, 2018). Acroleína produz irritação intensa e acentuada lacrimação (AUSTIN, 2008).

\subsubsection{Aldeídos}

Aldeídos são gases perigosos para a saúde dos combatentes de incêndios florestais. Eles são compostos orgânicos voláteis que causam irritação nos olhos, nariz e garganta, e a inalação pode causar inflamação nos pulmões com tosse, falta de ar e dor no peito. Quando o formaldeído (aldeído mais abundante) entra no corpo, ele é convertido em ácido fórmico tóxico. (GABBERT, 2018).

O Formaldeído produz irritação ocular quase imediata e uma forte sensação de queimação no nariz e na garganta, que pode estar associada a 
espirros, dificuldade em respirar fundo e tossir. Pode ocasinar lesão nas passagens respiratórias inferiores, irritação das vias aéreas superiores, aumento da resistência das vias aéreas, obstrução pulmonar e causar ferimentos graves nas vias respiratórias inferiores. É considerado um agente cancerígeno causador de leucemia em humanos. (AUSTIN, 2008).

\subsubsection{Dióxido de enxofre}

$\mathrm{O} \mathrm{SO}_{2}$ causa irritação severa nos olhos, pele, trato respiratório superior e membranas mucosas e pode causar broncoconstrição. Na presença de vapor de água, forma ácido sulfúrico e danifica as vias aéreas. (GABBERT, 2018). $O$ ácido sulfídrico é um produto da solução aquosa de sulfeto de hidrogênio, $\mathrm{H}_{2} \mathrm{~S}$, encontrado líquido ou gasoso (gás sulfídrico), irritante, altamente tóxico e inflamável (CARDOSO, 2019).

\subsection{Proteção Respiratória}

A proteção respiratória do combatente de incêndios florestais pode ser obtida a partir da prevenção à exposição perigosa associada ao uso de equipamentos adequados. Todo equipamento de proteção individual (EPI) de combate a incêndios florestais, incluindo a proteção respiratória, precisa aumentar a proteção contra chamas e temperaturas elevadas e reduzir 0 acúmulo de calor metabólico e estresse térmico. Austin, 2008, recomenda o uso de respirador purificador (motorizado ou não) para filtragem de material particulado (MP), vapores e ácidos orgânicos, acroleína, formaldeído e Hidrocarbonetos Policíclicos Aromáticos (HPA). Porém, considerando que os respiradores disponíveis no mercado não filtram o monóxido de carbono $(\mathrm{CO})$, indica o uso de um monitor de monóxido de carbono com alarme a fim de evitar exposição a intoxicação por $\mathrm{CO}$ tanto para quem usar ou não o respirador.

De Vos et al., 2006, demonstraram experimentalmente que o uso de filtros mais completos (MP, Vapores Orgânico (VO), Formaldeído) apresentou melhores resultados na filtragem da fumaça nas máscaras de bombeiros em áreas com fumaça de incêndios florestais reduzindo a tosse, chiado no peito $\mathrm{e}$ falta de ar, enquanto filtros mais simples (MP, VO) permitiam a passagem de acroleína e formaldeído. Tarín, 2013, demonstra que mais da metade dos 
combatentes de incêndios florestais espanhóis utilizam respiradores para sua proteção respiratória.

A Administração de Segurança e Saúde Ocupacional do Departamento de Trabalho dos Estados Unidos (OSHA, 2016) alerta que em fumaça densa os bombeiros com máscaras faciais podem permanecer por mais tempo tendo a impressão de que a inalação de fumaça foi reduzida e estão protegidos. Entretanto, isso pode levar a exposições mais longas a altas concentrações de componentes não filtrados tóxicos da fumaça podendo correr riscos desnecessários principalmente durante o rescaldo. Com o aumento da respiração em atividades extenuantes, a resistência da máscara e o estresse térmico podem causar uma sensação de falta de ar e claustrofobia. Portanto, um treinamento para isso deve ser conduzido no programa de proteção respiratória.

\subsubsection{Prevenção à Exposição}

Para gestão da segurança no programa de proteção respiratória, OSHA, 2016, recomenda as estratégias: envolver desde gestores até os combatentes, limitar a exposição à fumaça quando possível, trabalhar com o vento pelas costas sempre que possível, locar acampamentos e postos de comando em áreas a favor do vento e não propensas a inversões térmicas, atribuir missões e fazer pausas em áreas com pouca fumaça sempre que possível; instruir os bombeiros para: reconhecer sinais e sintomas de intoxicação, poluentes da fumaça e seus efeitos respiratórios, efeitos da visibilidade reduzida e comportamento de fumaça; monitorar rotineiramente a exposição à fumaça e seus efeitos nos bombeiros, avaliar regularmente os riscos para a saúde, utilizar dosímetros eletrônicos de monóxido de carbono sempre que possível, fornecer avisos instantâneos aos bombeiros quando os níveis de monóxido de carbono excederem os limites estabelecidos, e registrar ferimentos e doenças relacionadas com a fumaça nos bombeiros.

Se a fumaça é densa e não há como combater devido a alta concentração de $\mathrm{CO}$ e risco de intoxicação, considerar o combate indireto com fogo-contra-fogo em local onde a vegetação não vai gerar tanta fumaça ou ainda a construção de linha de fogo (aceiro de combate) afastado do local onde há muita fumaça. Outra alternativa é a barreira de espuma ou retardante a fim 
de se controlar o incêndio em local com menos fumaça. (NWCG, 2019). Em operações com grande circulação de viaturas e pessoal, molhar o solo e evitar arrastar os pés durante caminhadas para diminuição das partículas em suspensão de modo a reduzir aspiração de MP. (NIEHS/DHHS, 2014).

Um método alternativo de proteção contra a exposição à fumaça enquanto não se dispõe de respirador e detector de CO é o emprego de táticas de posicionamento a favor do vento, mantendo a fumaça à frente do combatente. (AUSTIN, 2008).

\subsubsection{Normatizações}

As atividades que mais expõem o bombeiro ao CO são o rescaldo, combate direto e uso de motosserra para as quais deve haver proteção respiratória. Portanto, devem ser normatizadas em relação à exposição aos contaminantes atmosféricos.

Conforme a ABNT NBR 12543/2017, o risco respiratório do combatente florestal pode se classificado como Não IPV8, contaminantes aerodispersóides (poeiras, fumos e radionuclídeos - eventualmente em regiões afetadas por radiação), gases e vapores (orgânicos e ácidos), portanto, mistura de aerodispersóides, gases e vapores. (BUSCHINELLI, 2020; TORLONI, 2016)

A Resolução CONAMA No 491/2018 que dispõe sobre padrões de qualidade do ar limita a $50 \mu \mathrm{g} \cdot \mathrm{m}^{-3}$ de $\mathrm{MP}_{10}$ e $25 \mu \mathrm{g} \cdot \mathrm{m}^{-3}$ de $\mathrm{MP}_{2,5} \mathrm{em} 24 \mathrm{~h}$. E para níveis de emergência $500 \mu \mathrm{g} \cdot \mathrm{m}^{-3}$ de $\mathrm{MP}_{10}, 250 \mu \mathrm{g} \cdot \mathrm{m}^{-3}$ de $\mathrm{MP}_{2,5}$ em $24 \mathrm{~h} . \mathrm{MP}_{10}$ com limite de tolerância estabelecidos pela Organização Mundial da Saúde em $50 \mu \mathrm{g} \cdot \mathrm{m}^{-3}$ durante $24 \mathrm{~h}$ por 8 a 12 vezes.

A Resolução CONAMA No 491/2018 limita a 9 ppm de CO a média móvel obtida em 8h, e para níveis de emergência 40ppm para CO em 8h, $35 \mathrm{ppm}$ em $1 \mathrm{~h}$. Órgãos de saúde californianos restringem a exposição nos incêndios florestais a $8 \mathrm{ppm}$ de Monóxido de carbono por um período de 24 horas, e 16 ppm para um turno de trabalho de 13 horas.

De modo geral, $30 \mathrm{ppm}$ de $\mathrm{CO}$ é a média de limite de exposição para $8 \mathrm{~h}$ que os países adotam, com um teto de 200ppm. A NR-7/1985 adota como parâmetro biológico de exposição ao $\mathrm{CO}$ o limite de $3,5 \%$ de $\mathrm{HbCO}$ (BUSCHINELLI, 2020). O Departamento de Relações Industriais do Estado da Califórnia (DIR/SCa, 2019) recomenda que os empregadores adotem medidas 
de proteção respiratória de seus trabalhadores expostos a atmosfera contaminada por fumaça de incêndios florestais, inclusive com o uso de respiradores, exigentemente caso $\circ \mathrm{MP}_{2,5}$ ultrapasse 500 ppm. $O$ código de saúde dos Estados Unidos da América que aprova os dispositivos de proteção respiratória estabelece que a resistência à inalação de aparelhos de circuito aberto não deve exceder 32 mmca a uma vazão de 120 l/min. (DHHS, 2019).

A NFPA 1984 especifica os requisitos mínimos de projeto, desempenho, teste e certificação para os respiradores, acessórios e aprimoramentos que fornecerem proteção contra riscos de inalação não IPVS em operações de combate a incêndios florestais. Apesar de reconhecer que não exista uma norma específica para proteção respiratória durante o combate a incêndio florestal, o Instituto Nacional de Segurança e Higiene do Trabalho (INSHT) da Espanha recomenda o uso de mascarilhas ou adaptadores faciais de filtros (máscara facial completa ou meia máscara), em função dos riscos a partir das normas UNE- EN 136:1998, 140:1999, 143:2001, 149:2001,405:2002, 1487:2004, contra gases, vapores e partículas.

Torloni et al., 2016, tratando da normatização do Programa de Proteção Respiratória (PPR) indicam que o uso de respiradores só deve ser adotado caso medidas de mitigação da exposição não sejam suficientes à manutenção de atmosfera segura para respiração dos trabalhadores. Dessa maneira, o posicionamento tático com vento pelas costas, a rendição dos combatentes nas áreas com maior concentração de gases, o uso de linha de fogo, o combate aéreo e o combate químico, não são suficientes para garantir um controle da exposição, pois o combatente ainda se exporá à fumaça.

Torloni et al., 2016, caracterizam o combate a incêndio como uma Aplicação Especial a qual não se adequa no Programa de Proteção Respiratória instituído pela Instrução Normativa $n^{\circ}$ 01/1994 do Ministério do Trabalho e Emprego, sendo indicado para este caso as recomendações do $\mathrm{NIOSH}$ e CDC dos EUA. Ainda assim, o PPR traz uma formatação adequada para um programa de proteção respiratória dos combatentes de incêndios florestais, sendo necessárias as devidas adequações e adaptações, tornandose um Programa de Proteção Respiratória Especial. 


\subsubsection{Posicionamento Tático de combate e prevenção}

O posicionamento tático consiste em recuar de áreas onde os níveis de $\mathrm{CO}$ excedem os limites de exposição ocupacional, e posicionar-se para o combate em local onde os níveis de fumaça estejam menores. Larsen et al., 2015, demonstraram experimentalmente em condições laboratoriais que os bombeiros podem trabalhar eficientemente durante mais de 6 horas sem estresse térmico e cardíaco, contanto que houvesse rendições periódicas e acesso livre à hidratação, embora houvesse grande desidratação. A pesquisa aponta para de exposição perigosa em $20 \%$ do tempo do combate, o que pode levar a intoxicações (YOUSSOUF et al., 2014).

Reinhardt e Ottmar, 2004, observaram que quanto menor a velocidade do vento maior a exposição aos poluentes e que o material particulado aumenta com os as poeiras em suspensão pelo arrastamento dos pés ou materiais. Portanto, em locais com pouco vento, deve-se evitar a queima prescrita, pois muitas vezes excedem os limites de exposição. Se o vento ambiental for forte, pode dispersar a pluma sobre os bombeiros. Porquanto, dar preferência para queima em ventos moderados, pois o ar fresco é puxado para as bordas da queima protegendo os bombeiros que estão no perímetro.

O Grupo de Coordenação Nacional de Incêndios Florestais americano (NWCG, 2012), recomendou que os bombeiros florestais não utilizassem respiradores a não ser que fosse estabelecido um programa de proteção respiratória aprovados pelo Instituto Nacional de Saúde Ocupacional cumprindo as normas do NFPA, além de estabelecer ações de mitigação da exposição à fumaça, entre elas: rendição das equipes em zonas de maior exposição; deixar queimar áreas que estejam gerando muita fumaça aguardando para combater em local com menor concentração de gases; usar equipamentos (lançadores de espuma/ retardantes, viaturas, tratores) em zonas de alta concentração de gases; planejar o fogo prescrito para condições que favoreçam a baixa produção de fumaça; monitorar a concentração de $\mathrm{CO}$; estabelecer acampamento em local livre da fumaça.

Entre os parâmetros de proteção, a NIOSH, 2013, recomenda a manutenção da saúde como fator preponderante (atividade física, alimentação, sono e não fumar) e se estiver exausto, o combatente deve fazer pausas em áreas frescas para hidratar-se. A limitação a exposição deve ser gerenciada de 
modo a permitir rotação de equipe em caso de fumaça densa, evitar o combate na fumaça, usar EPR para minimizar exposição durante o rescaldo, o chefe ou gestor da equipe deve monitorar a situação de saúde dos combatentes, localizar viaturas e acampamentos contra o vento.

\subsubsection{Equipamentos para proteção respiratória}

Ao selecionar um respirador, deve-se considerar o peso, o ruído, a robustez e a duração da bateria. $O$ uso de respiradores exige a implementação de um programa formal de proteção respiratória, incluindo testes de adaptação e de capacidade respiratória com o equipamento escolhido. Sabe-se que nenhum respirador protege contra todos os componentes tóxicos presentes na fumaça. A eficácia e a duração dos filtros pode ser comprometida por longos períodos de combate bem como pelo derretimento, devendo-se atentar para a troca dos cartuchos e filtros. (AUSTIN, 2008). Ao utilizar a árvore de decisão para seleção de aparelhos de proteção respiratória de Almeida et al., 2016, depara-se com a indicação de aparelho de respiração autônomo caso a atmosfera de exposição tem contaminante em concentrações imediatamente nocivas como é o caso dos incêndios florestais.

Austin, 2008, recomenda que o dispositivo adotado também ofereça proteção aos olhos visto que os combatentes de incêndios florestais passam por uma super exposição a substâncias irritantes, incluindo formaldeído. Os respiradores motorizados diminuem o esforço ventilatório, porém acrescentam peso, ruído, volume e uma bateria que precisa ser recarregada. Para os incêndios em interface urbano-florestal com resíduos urbanos em zonas com concentração de fumaça deve-se utilizar EPR Autônomo, pois o combatente está exposto aos mesmos gases do incêndio estrutural.

Haston, 2007, alerta para situação de incêndio na interface urbano florestal a necessidade de EPR Autônomo com cilindro de ar pois há gases tóxicos como no incêndio estrutural. No entanto, o EPRA é impraticável para a maioria dos combates a incêndios florestais devido ao seu peso e volume altos e autonomia limitada a 60 minutos. Deve-se considerar o uso de EPRA, caso haja necessidade de trabalhar em zonas de alta concentração de $\mathrm{CO}$ por muito tempo, pois os respiradores não oferecerão filtração adequada e haverá 
intoxicação do combatente. (NIEHS/DHHS, 2014). Máscaras podem filtrar partículas suspensas, mas não promovem proteção contra gases aquecidos e tóxicos (SOUZA, 2011).

Se a concentração de Monóxido de Carbono estiver abaixo de 150 ppm, é aceitável um respirador purificador de ar para vapores orgânicos, gases ácidos e aldeídos com filtro de alta eficiência para partículas, desde que haja um programa de proteção respiratória e os bombeiros estejam treinados também para descontaminação dos equipamentos (GRIMWOOD et al., 2005). Austin e Coyer, 2007, recomendam o uso de máscaras com detectores de CO para proteção respiratória do combatente até que haja respiradores específicos. Há que se considerar ainda que os respiradores precisam oferecer proteção contra o superaquecimento do ar que pode causar lesões pulmonares, inflamação do material da máscara e do filtro. Deve haver uma avaliação médica, treinamento e teste de adequação/ vedação dos respiradores, bem como o usuário não pode possuir pelos no rosto ou estar usando adornos.

Austin, 2008, recomenda respiradores purificador de ar certificados ou motorizados seja usado para partículas respiráveis, vapores e ácidos orgânicos, acroleína, formaldeído e HPAs. No entanto, se o respirador não remove efetivamente o monóxido de carbono, ele deve ser usado com um monitor de monóxido de carbono que emita um alarme sonoro e vibração em um ponto de ajuste predeterminado para avisar quando a exposição ocupacional limite de $\mathrm{CO}$ foi excedida. Se isso ocorrer, os combatentes devem adotar o posicionamento tático, a fim de limitar a exposição. Os monitores de CO também devem ser usados por profissionais sem respirador em áreas enfumaçadas.

Como os níveis de $\mathrm{CO}$ se correlacionam com os níveis de outros componentes tóxicos da fumaça, o ponto de ajuste deve ser fixado em uma concentração de $\mathrm{CO}$ onde espera-se níveis de CO, formaldeído, acroleína, HPA, material particulado estejam abaixo de seus respectivos limites de exposição ocupacional e o índice de irritação seja baixo (AUSTIN, 2008).

Um respirador facial completo oferece um fator de proteção muito maior que uma meia máscara, pois também fornece a proteção dos olhos contra substâncias irritantes, como o formaldeído. Todo respirador reduz a capacidade 
de trabalho. Sendo assim, e se os combatentes tiverem dificuldades de uso do respirador adotado, pode-se optar por respiradores purificadores de ar acionados de pressão positiva que oferecem fatores de proteção aumentados e resistência respiratória reduzida, o que é especialmente importante em altos níveis de trabalho. (AUSTIN, 2008).

O combatente deve estar clinicamente saudável para usar o respirador escolhido, ter feito o treinamento e o teste (NIEHS/DHHS, 2014). Em seu treinamento de resposta a incêndios florestais, a NIEHS alerta que os retardantes químicos redutores da inflamabilidade podem causar câncer, mas não tem seus efeitos bem conhecidos. A NIEHS recomenda o uso de respiradores meia máscara ou máscara completa aprovados N-95 a P-100 com uma série de filtros. $P 100$ deve ser usado caso haja retardantes ou cinzas em suspensão no ar. Associado ao uso de respiradores, a NIEHS recomenda controle das poeiras que podem conter resíduos de retardantes, cinzas, amianto e sílica por meio de molhação de área com muita poeira onde os bombeiros vão passar, filtros HEPA, e evitar longas filas de bombeiros durante o deslocamento a fim de evitar que o arrastamento dos pés gere muito material suspenso no ar.

O uso de respiradores deve estar associado ao dosímetro eletroquímico de $\mathrm{CO}$, pois os demais gases são irritantes e afastam o bombeiro enquanto $\mathrm{O}$ CO é inicialmente assintomático, porém muito tóxico (REINHARDT e OTTMAR, 2004). Além do mais, a proteção adequada leva a um maior rendimento e efetividade do trabalho, consequentemente reduzindo a área queimada.

\subsubsection{Manutenção dos equipamentos}

Pessoas possuidoras de doenças cardiorrespiratórias, asma, enfisema pulmonar, só podem utilizar respiradores com autorização médica. Para usar um respirador é preciso estar sem nada entre a máscara e o rosto. Deve-se evitar o compartilhamento do respirador a fim de impedir a contaminação cruzada. (ALMEIDA, 2016). Deve-se inspecionar o respirador toda vez que o colocar (verificando o selo) e tirar. Os respiradores devem ser limpos ou lavados no dia em que usar, de acordo com recomendações dos fabricantes. Os respiradores elastoméricos devem ser armazenados em um saco limpo. Se 
o respirador ficar danificado ou não funcionar, deve-se providenciar outro. (NIEHS/DHHS, 2014).

Sbihi et al., 2014, alertam para o fato da efetividade dos respiradores estar necessariamente associada à vedação. Para garantir que o ar inalado passou apenas pelos filtros, com as aberturas vedadas, o usuário deve fazer os testes de pressão: positiva- expirando até notar o estufamento da máscara; e negativa- inspirando e percebendo um encaixe total na face.

Os cartuchos de filtros devem ser trocados quando houver dificuldade de respirar ou se detecte algum odor de vapores orgânicos atravessando o filtro (NIEHS/DHHS, 2014). Espirros, tosse e chiado no peito podem ser reduzidas com o uso de máscaras, bem como podem exacerbar sintomas de problemas respiratórios ao aumentar o esforço ventilatório especialmente quando ultrapassam o limite de tempo de uso perdendo a pressão elastomérica e sobrecarregando o filtro de contaminantes (SBIHI et al., 2014).

Os monitores de $\mathrm{CO}$ precisam de carregamento das baterias e podem precisar de calibração a depender do modelo.

\subsubsection{Indústria e mercado de equipamentos}

Poucas indústrias de EPRs têm produtos destinados especificamente para proteção respiratória do combatente florestal. Algumas apresentam o tema para incêndios florestais, porém ao analisar o conteúdo não há nenhuma indicação de equipamento adequado para proteção respiratória contra os gases de incêndios florestais. Apesar de ter um custo relativamente alto, alguns EPIs disponíveis no mercado não oferecem a proteção contra os gases tóxicos.

Entre as marcas pesquisadas, a única indicada para combate a incêndio florestal foi a russa que o fabricante indica adequada para proteção contra fumaça de incêndios florestais. $O$ respirador deles com dois filtros exclusivos é capaz de reduzir a concentração dos gases da combustão em 50 vezes, incluindo $\mathrm{CO}$ com propriedades ergonômicas e protetoras, compatíveis com os óculos de proteção, segundo o fabricante.

Recentemente uma empresa lançou um modelo que está indicado para combate a incêndios florestais- trata-se de um respirador elastomérico (silicone) e termoplástico de cartucho frontal (intercambiáveis de acordo com a necessidade de proteção) revestido por tecido ininflamável. O fabricante indica- 
o para todos os tipos de face e situações mais diversas para o combate. Essa empresa dispõe ainda de um respirador para situações em que a vida está ameaçada. A partir de reações químicas, esse equipamento recicla $\circ$ ar exalado.

\subsubsection{Filtros de cartuchos para respiradores}

Os filtros apenas de partículas não retêm os gases. Quando o combatente usa máscaras para partículas como a N95 ou PFF2 pode apresentar mais sintomas respiratórios que outros protegidos com filtros mais completos (YOUSSELF et al, 2018). Trabalhar em combate a incêndio florestal representa risco de ignição para os filtros de carvão ativado podendo acumular concentrações tóxicas perigosas, se sua temperatura no material superar os 93 ${ }^{\circ} \mathrm{C}$ que é o seu ponto de fulgor (INTRALAB, 2020).

Cone, 1992, sugeriu cartuchos de carvão com fibra de vidro como filtros e indicadores de $\mathrm{CO}$. Mas o equipamento apresentava duração de apenas uma hora em fumaça densa e $6 \mathrm{~h}$ em fumaça leve. Geralmente os cartuchos multigases são para gases ácidos, vapores orgânicos e outros tóxicos, associados a filtros de partículas finas sendo, portanto, os mais indicados para proteção respiratória do combatente enquanto não possui um equipamento específico.

Cartuchos de filtros específicos para monóxido de carbono são comercializados. Eles até retêm outros gases tóxicos e materiais particulados, porém com uma durabilidade de filtração muito baixa. Esse filtro tem algumas restrições que limitam seu uso no combate a incêndio florestal como o limite de temperatura e uma concentração máxima de $\mathrm{CO}$ no tempo, sendo recomendado exclusivamente para $\mathrm{CO}$. Como no CIF há vários outros gases tóxicos, esse filtro se torna incompatível.

O sistema em desenvolvimento proposto pelo governo americano é composto por um módulo filtrante que remove até o material particulado muito fino com carvão adsorvente para remoção dos vapores químicos tóxicos e um catalisador a temperatura ambiente que remove o $\mathrm{CO}$, além do módulo indicador do fim da vida útil sinalizando a necessidade de troca do cartucho filtrante. Eles estão em fase de teste. (DHS/DSC, 2018, 2020). 
Pesquisadores da Universidade Estadual de Washington (EUA) desenvolveram um filtro que retém gases tóxicos de incêndios florestais a partir de materiais orgânicos. Eles utilizaram proteínas de soja e celulose bacteriana para criar um material filtrante capaz de reter o material particulado e também gases como $\mathrm{CO}$, acroleína e formaldeído. Os gases são retidos por afinidade química com a matriz molecular. Essa tecnologia apresenta grande vantagem do baixo custo e da biodegradação, dessa forma diminuído a geração de resíduos e sendo sustentável ecológica e economicamente. Eles aguardam parcerias com indústrias para comercialização do material. (HILDING, 2017).

\subsubsection{Respiradores}

Um respirador indicado deve ser capaz filtrar vapores orgânicos, gases ácidos e material particulado fino, além de Dióxido de Enxofre, Formaldeído, Metilamina e Gás Sulfídrico (CARDOSO, 2019). Ele pode ser de meia peça (semifacial) com cartucho combinado de vapor orgânico / gás ácido e filtro N95. Ele é $95 \%$ eficiente na filtragem de partículas de 0,3 $\mu \mathrm{m}$ (mícron), preferencialmente com material absorvente para reduzir gases e vapores incômodos e resistente ao calor e à propagação de chama (HASTON, 2007). Para o combatente florestal há necessidade de: válvula de exalação para alívio do calor e umidade, diafragma de voz para comunicação, resistência a arranhões e ao calor, bem como filtros trocáveis, preferencialmente P100.

Para o uso de respiradores com filtro de cartucho, é recomendado a quantificação da capacidade ventilatória que pode ser feita com espirômetro e manovacuômetro por um médico pneumologista. A pressão inalatória máxima vai indicar a capacidade do combatente de inalar mesmo estando utilizando os cartuchos que aumentam a resistência ao fluxo de ar. A medida da pressão exalatória vai mostrar a capacidade de exalar, pois também é limitada pelas máscaras. (PARREIRA, 2007; PESSOA, 2013; MONTEZZUMO, 2015). Por isso, os cartuchos adotados devem permitir uma adequada taxa de fluxo inalatório e exalatório. $O$ fluxo inalatório é propiciado por uma matriz filtrante não só mecânica, mas adsorvente. Já o fluxo exalatório é garantido por válvulas exalatórias que permitam a saída de todo volume exalado. 
O respirador atualmente disponível no mercado desenvolvido para o combate a incêndios florestais apresentam-se como meia máscara facial de silicone com duas flanges de vedação e diafragma de voz, que propaga claramente a voz do usuário sem que ele tire o respirador. Ele vem com cartucho combinado para multi-contaminante (inclusive retêm o $\mathrm{CO}$ e os outros contaminantes da fumaça), associado a filtro de partículas P-3. Há ainda a proteção do tipo bandana que recobre um respirador de silicone com um filtro frontal com tecido.

Há ainda as máscaras tipo bandana de tecido muito resistente ao calor que se sobrepõe ao respirador com cartucho de filtro completo. Alguns suportam até $1400{ }^{\circ} \mathrm{C}$, protegendo contra queimaduras e partículas, mas não filtra o monóxido de carbono (CO).

O uso de respiradores de face completa favorece o conforto do combatente ao passo que evitam o contato das mucosas (olhos, boca, traquéia e brônquios) e a irritação e "queimação causadas pela fumaça. Eles têm um fator de proteção atribuído 10 vezes maior que os respiradores de meia face. (NWCG, 2019)

Uma empresa oferece o Respirador Reutilizável Facial Inteira que dispõe de válvula de alívio de calor e umidade, visor com anti sujeira e amplo campo visual, diafragma de voz. Possui diafragma de voz e válvula de exalação de calor e umidade. Associa-se ao filtro combinado para vapores orgânicos, gases ácidos, formaldeído e material particulado, além de outros gases. Outra empresa oferece respirador com válvula de expiração e filtros universal com retenção de $\mathrm{CO}$ maior que $20 \mathrm{~min}$. Nesse, o cartucho de alumínio é resistente à altas temperaturas e indicado para proteção contra fumaça de incêndios florestais.

O respirador purificador energizado tem fator de proteção atribuído de 1000 e garante um fluxo de ar de ao menos $160 \mathrm{~L} / \mathrm{min}$. Ele suporta temperatura de operação de até $50^{\circ} \mathrm{C}$, e mesmo assim pode-se ter pressões negativas no interior da máscara em condições de trabalho extremamente duras. Outro fabricante oferece respirador indicado para bombeiros com vedação em silicone, lente anti-embaçante, conexão frontal para cartuchos intercambiáveis, válvulas de exalação e diafragma de voz. Esse apresenta resistência inalatória 
máxima de 0,5 mbar, 1,5 mbar e 2,5 mbar com fluxos constantes de $30 \mathrm{l} / \mathrm{min}$, $95 \mathrm{l} / \mathrm{min}$, e 160l/min, respectivamente atendendo a norma DIN EN 136.

\subsubsection{Monitor de Monóxido de Carbono}

Como os contaminantes com propriedades de advertência (odor ou efeitos irritantes) são removidos pelos respiradores purificadores de ar, pode haver exposição a níveis mais altos de contaminantes tóxicos que o respirador não removeu. Isso poderia resultar em exposição excessiva ao CO. Para evitar isso, um monitor de $\mathrm{CO}$ com alarme deve ser usado em conjunto com respiradores de purificação do ar usados no combate a incêndios florestais. Os chefes das guarnições/equipes seriam os portadores desses monitores. Como os "níveis de $\mathrm{CO}$ se correlacionam com os níveis de outros componentes tóxicos da fumaça" deve-se estabelecer o nível de CO seguro em que os outros gases tóxicos também estejam em níveis seguros, especialmente para os Acroleína e HPA, que não são especificamente filtrados pelos cartuchos indicados. Adicionalmente, pode-se utilizar o monitor de material particulado calibrado em $1 \mathrm{mg} / \mathrm{m}^{3}$ para indicar a necessidade de uso de proteção respiratória reduzindo a exposição em até 74\%. (AUSTIN, 2008; EDWARDS et al., 2005)

Uma empresa fornece um monitor de $\mathrm{CO}$ indicado para Bombeiros. Outra fabricante oferece o Detector monogás com 5 anos de garantia, possível manutenção com troca de sensores e baterias. Outro fabricante oferece monitor de $\mathrm{CO}$ pessoal que pode operar até $65^{\circ} \mathrm{C}$ (mais alta na categoria). $\mathrm{O}$ fabricante promete robustez e simplicidade com alarmes certamente notáveis pré-ajustados de acordo com os limites de exposição ocupacional máxima e média no tempo, bem como interface e calibração com computador pessoal.

\subsection{Engenharia de materiais}

Outro problema sobre o uso das máscaras não específicas é verificar se elas suportam altas temperaturas, pois os incêndios florestais no cerrado atingem até $884^{\circ} \mathrm{C}$ (MIRANDA, 2010) o que pode levar a degradação térmica dos componentes da máscara e até gerar mais tóxicos do que os presentes na fumaça do incêndio florestal. Pastore e Iramina, 2009, analisando a resistência de vários EPR observaram que em altas temperaturas os filtros de fibras 
carregadas eletrostaticamente contra particulados diminuem sua capacidade com o aumento da temperatura. Daí a necessidade de filtros específicos para situação de combate a incêndios florestais pois devem suportar temperaturas elevadas.

Em geral, os respiradores são feitos de termoplásticos (polietileno, polipropileno, cloreto de vinila, poliestireno ou poliuretano), silicone, plástico $A B S$ e viseiras de policarbonato. Entre esses materiais, o silicone tem a menor temperatura para iniciar sua decomposição térmica que é de $145^{\circ} \mathrm{C}$ (HURLEY et al., 2002).

O filtro pode ser feito com carvão ativado, micro fibra de vidro e papel plissado que retira os contaminantes por filtração e adsorção. Comparando-se os diversos cartuchos filtrantes de um fabricante, percebe-se que por mais que o cartucho seja especificado para muitos contaminantes, mantêm-se a mesma resistência para inalação respiratória. Em atividades de esforço máximo em combate a incêndio o consumo de ar pode chegar a $135 \mathrm{l} / \mathrm{min}$, geralmente em menos de $5 \mathrm{~min}$. Nos trabalhos muito pesados que podem durar cerca de $2 \mathrm{~h}$ sem interrupção o consumo é de $85 \mathrm{l} / \mathrm{min}$ (TORLONI et al, 2016).

O Departamento de Segurança Interna (DHS) do Governo dos Estados Unidos testa protótipos de filtros específicos para remoção das partículas e vapores químicos perigosos da fumaça de incêndio que podem ser usados em uma ampla variedade de respiradores de purificação de ar. Os pesquisadores já testaram vários materiais de carvão ativado e filtros de partículas contra contaminantes que normalmente são encontrados durante o rescaldo. $O$ filtro de partículas escolhido é do tipo HEPA (alta eficiência na separação de partículas) e está associado ao carvão ativado para adsorção de gases ácidos, amônia / amina, vapor orgânico e multigases de carbono. Esse cartucho estará associado a um módulo catalisador de oxidação de $\mathrm{CO}$ à temperatura ambiente opcional em que o $\mathrm{CO}$ é oxidado em $\mathrm{CO}_{2}$.

\section{RECOMENDAÇÕES}

\subsection{Programa de Proteção Respiratória}

É necessário desenvolver um programa de proteção respiratória em equilíbrio entre a necessidade de proteção respiratória contra níveis 
intermitentemente altos de fumaça, a necessidade de um grau razoável de conforto ao trabalhar em um ambiente quente por longos períodos em áreas remotas executando tarefas fisicamente exigentes e a necessidade de controlar e extinguir incêndios florestais. Os combatentes deverão ser orientados sobre à limitação do EPR quanto a intoxicação por gases específicos. Deverá ser implantado um programa de manutenção (limpeza, reposição dos filtros, e troca) dos EPRs florestais. (NR9 9.3.5.5).

Dentro do PPR (Programa de proteção respiratória), é recomendável o monitoramento biológico da exposição ocupacional por meio de exames laboratoriais de biomarcador sensível a xenobióticos com indicadores de efeito. A inflamação, que é o fator mais comum em decorrência da exposição à fumaça, pode ser testada pela quantidade de granulócitos no escarro como resposta ao material particulado e a carboxihemoglobina como indicadora do efeito do monóxido de carbono. (YOUSSOUF et al., 2014; BUSCHINELLI, 2020)

\subsection{Análise e planejamento de combate}

Estabelecer uma doutrina de proteção contra fumaça nas instruções, cursos, treinamentos e simulacros favorecerá a proteção respiratória. Em cada ocorrência, analisar a fumaça a fim de obter informações sobre a segurança do combate em determinadas áreas com muita fumaça. Mesmo sem o uso do Monitor de $\mathrm{CO}$, se a fumaça for densa sabe-se que o limite de exposição será superado em pouco tempo. Sempre estabelecer o posto de comando ou o acampamento em locais não propícios a fumaça. Em ambientes com muita fumaça na cabeça do incêndio estabelecer um aceiro (em solo mineral ou aceiro químico com retardante ou/e espuma) para evitar a superexposição. No caso de combate químico, deve-se atentar ao maior risco de exposição à fumaça perigosa.

Ao final dos turnos, deve-se observar as condições de saúde dos combatentes. Dor no peito (angina), fadiga excessiva, sensação de indigestão e falta de ar excessiva, são sinais de alerta precoce que precedem eventos cardíacos fatais devem ser relatados (YOUSSOUF et al., 2014). 


\subsection{Aquisição de Equipamentos}

Todos equipamentos para proteção respiratória devem ser adquiridos no âmbito do PPR, em que a comissão assessorada por um médico pneumologista tomará as medidas cabíveis. Enquanto não se dispor de um equipamento de proteção suficientemente efetivo e adequado à proteção respiratória contra os gases tóxicos no local de combate, sugere-se a utilização de máscaras faciais completas conforme a NR-9 MT BR associado a monitores de CO. As medidas de organização do trabalho preconizadas na NR 9 9.3.5.4 podem ser implementadas com a recomendação de posicionamento do combatente em locais com menor concentração de fumaça e utilização do EPI recomendado.

Alternativamente, o respirador de meia face com cartucho multigases e filtro P100 coberto por balaclava não inflamável, associado a óculos de proteção de ampla visão podem fornecer uma relativa proteção ao passo em que se adotem medidas de posicionamento tático. Dessa maneira, são mantidos os sinais de alerta dos gases irritantes nos olhos, pois os óculos não impedem sua entrada. Neste caso, deve-se manter atenção redobrada nos sinais e sintomas de intoxicação e consciência da não retenção do CO, HPAs, Acroleína e outros tóxicos.

Recomenda-se o uso de detector monogás para Monóxido de Carbono por ao menos um dos membros da equipe de Combate a Incêndios Florestais (CIF). Os monitores de $\mathrm{CO}$ devem ser calibrados para alarme de limite emergencial e de média por hora/turno. Quando houver alerta para alta concentração, verificar o percentual de carboxihemoglobina no sangue do combatente por meio de um pulso-oxímetro/carboximetro.

\section{CONCLUSÃO}

Pelo presente estudo e considerando toda bibliografia citada, conclui-se que a fumaça dos incêndios florestais se apresenta como perigosa aos combatentes de incêndios florestais podendo causar sintomatologias e patologia de curto a longo prazo. Portanto, é necessário a adoção de medidas para redução da exposição iniciando com posicionamento tático, revezamento das equipes no combate à cabeça do incêndio, bem como a utilização de respiradores de qualidade com materiais seguros e com filtros que retenham 
Revista Científica do Corpo de Bombeiros Militar de Pernambuco

Artigo Publicado no Vol.06 N.17 - Edição Jul a Dez 2020 - ISSN 2359-4829

Versão on-line disponível em: http://www.revistaflammae.com

não só Material Particulado fino, mas também Vapores Orgânicos e Gases Ácidos, e se possível que retenham ainda $\mathrm{CO}$. Associado ao respirador é necessário o uso de um monitor de $\mathrm{CO}$ a fim de limitar a exposição aos contaminantes tóxicos. Essas ações podem mitigar a intoxicação e a morbimortalidade dos combatentes florestais brasileiros. Elas devem ser adotadas no âmbito de um Programa de Proteção Respiratória institucional coordenado por uma comissão assessorada por um médico pneumologista.

\section{REFERÊNCIAS}

ADETONA, et al. Review of the health effects of wildland fire smoke on wildland firefighters and the public, Inhalation Toxicology, 28:3,95-139,2016.

AGER, Alan A. et al. The wildfire problem in areas contaminated by the Chernobyl disaster. Science of the Total Environment, v. 696, p. 133954, 2019.

ALENCAR, Paola Aires Lócio de. Condição laboral de combatentes do fogo em relação ao monóxido de carbono e material particulado. TCC de graduação. Departamento de Engenharia Florestal da Universidade de Brasília. Orientadores: Eraldo Matricardi e Carlos Henke. 2018.

ALMEIDA, Teresa [et al.]. Guia de seleção de aparelhos de proteção respiratória filtrantes. Lisboa: ACT, 2016; .

ALVES, Nilmara de Oliveira. Os efeitos das queimadas na Amazônia em nível celular e molecular. 2014. 133f. Tese (Doutorado em Bioquímica) - Centro de Biociências, Universidade Federal do Rio Grande do Norte, Natal, 2014.

ANGELUCCI, Camilo Andréa. Alguns aspectos da eletroxidação de monóxido de carbono em superfícies monocristalinas de platina de baixo e alto índice de Miller. 2007. (Doutorado em Físico-Química) - Instituto de Química, Universidade de São Paulo, São Carlos, 2007. doi:10.11606/T.75.2007.tde30082007-104454. Acesso: 24jan2020.

ABNT. NBR 12543: Equipamentos de proteção respiratória. RJ:, 2017.

AUSTIN, C. Wildland Firefighter Health Risks and Respiratory Protection (Report R-572). Montreal, Quebec, Canadá: IRSST (Institut de recherche Robert-Sauvé en santé et en sécurité du travail), 2008.

BERNSTEIN. Wildfire Smoke Air Pollution: Health Hazards \& Advice What is known \& not known What can we do in planning \& responding Pre-Fire 
Revista Científica do Corpo de Bombeiros Militar de Pernambuco

Artigo Publicado no Vol.06 N.17 - Edição Jul a Dez 2020 - ISSN 2359-4829

Versão on-line disponível em: http://www.revistaflammae.com

Season Briefing, 4/15/2019 Dr. Bob Bernstein, MD, PhD, MPH Tuolumne County Health Officer

BUSCHINELLI, José Tarcísio Penteado. Toxicologia ocupacional. São Paulo: Fundacentro, 2020.

CARBALLO, B. Leyenda et al. Exposure to carbon monoxide in wildland firefighters during wildfires suppression. Revista espanola de salud publica, v. 84, n. 6, p. 799-807, 2010.

CARBALLO-LEYENDA, Belén et al. "Characterizing Wildland Firefighters' Thermal Environment During Live-Fire Suppression." Frontiers in physiology vol. 10949. 2 Aug. 2019.

CONAMA. Resolução CONAMA N 491/2018 - Dispõe sobre padrões de qualidade do ar.

CONE, M. Mask Seems Blessing for Firefighters : Safety: New respirators hold promise for crews who have fought wildfires with just bandannas to protect their lungs. LOS ANGELES TIMES BY MARLA CONE. DEC. 8, 1992. / Los Angeles Times online.

DE OLIVEIRA ALVES, Nilmara et al. Biomass burning in the Amazon region causes DNA damage and cell death in human lung cells. Scientific reports, v. 7, n. 1, p. 10937, 2017.

DE VOS, Annemarie JBM; COOK, Angus. Effect of protective filters on fire fighter respiratory health during simulated bushfire smoke exposure in Western Australia. Forest Ecology and Management, n. 234, p. S143, 2006.

DHS/STD. Department of Homeland Security. Science and Technology Directorate. Wildland Firefighter Respiratory Protection. 2018-06-06.

EDWARDS, Rufus et al. Application of real-time particle sensors to help mitigate exposures of wildland firefighters. Archives of environmental \& occupational health, v. 60 , n. 1, p. 40-43, 2005.

FAM/USFS. Fire and Aviation Management U.S. Forest Service. HUMAN HEALTH RISK ASSESSMENT OF WILDLAND FIRE-FIGHTING CHEMICALS: LONGTERM FIRE RETARDANTS. December 2013.

FÉLIX, Gleidson de Araújo et al. AVALIAÇÃO DA EFICIÊNCIA DE COMBATE AOS INCÊNDIOS FLORESTAIS EM UNIDADES DE CONSERVAÇÃO BRASILEIRAS. FLORESTA, [S.I.], v. 48, n. 1, p. 113 - 122, mar. 2018.

FORD, B. et al. Future fire impacts on smoke concentrations, visibility, and health 
Revista Científica do Corpo de Bombeiros Militar de Pernambuco

Artigo Publicado no Vol.06 N.17 - Edição Jul a Dez 2020 - ISSN 2359-4829

Versão on-line disponível em: http://www.revistaflammae.com

in the contiguous United States. GeoHealth, v. 2, n. 8, p. 229-247, 2018.

GABBERT, Bill. Study shows firefighters' exposure to smoke increases disease risk. Wildfire Today. Posted on February 6, 2018.

GALLO, Jorge B.; AGNELLI., José A. M.. Aspectos do comportamento de polímeros em condições de incêndio. Polímeros, São Carlos, v. 8, n. 1, p. 23-38, Mar. 1998.

GIANNIOU N, Giannakopoulou C, Dima E, et al. Acute effects of smoke exposure on airway and systemic inflammation in forest firefighters. J Asthma Allergy. 2018;11:81-88. Published 2018 Apr 23. doi:10.2147/JAA.S136417

GRIMWOOD, Paul; HARTIN, Ed; MCDONOUGH, John. 3D Fire Fighting: Training, Techniques, and Tactics. Fire Protection Publications, Oklahoma State University, 2005.

Haston, David. United States Department of Agriculture. Forest Service. National Technology \& Development Program Fire. Management Tech tips Respirator Usage by Wildland Firefighters. March 2007.

HILDING, T. Researchers develop environmentally friendly, soy air filter. WSU INSIDER. January 12, 2017.

HODGSON, Amy K. et al. Near-field emission profiling of tropical forest and Cerrado fires in Brazil during SAMBBA 2012. Atmospheric Chemistry and Physics, v. 18, n. 8, p. 5619-5638, 2018.

HVENEGAARD, Steven. Health impact of smoke exposure in wildland-urban interface fires: a literature review. 2012. Wildfire Operations Research 1176 Switzer Drive Hinton AB T7V 1V3

INSHT. LAGUNA, A. L.; RUIZ, S. T. EPI para lucha contra incendios forestales: Resumen Normativo. Centro Nacional de Medios de Protección. Ministerio de trabajo e inmigración. Instituto Nacional de Seguridad e Higiene en el Trabajo.

LEMAN, Jennifer. How This Researcher Invented an Entirely New-and Entirely Badass. Leda Kobziar and other pyroaerobiologists find life up in smoke- Literally. Popular Mechanics. Dec, 2019.

LEMOS, Vinícius. Saúde ou emprego? O dilema do amianto, que fez Goiás desafiar STF. BBC News Brasil online. Cuiabá, MS. 11 setembro 2019.

MAYER, Alexander C. et al. Firefighter hood contamination: Efficiency of laundering to remove PAHs and FRs. Journal of occupational and environmental hygiene, v. 16, n. 2, p. 129-140, 2019. 


\section{Revista FLAMMAE}

Revista Científica do Corpo de Bombeiros Militar de Pernambuco

Artigo Publicado no Vol.06 N.17 - Edição Jul a Dez 2020 - ISSN 2359-4829

Versão on-line disponível em: http://www.revistaflammae.com

MONTEZZUMO, Dayane. Estudo sobre a avaliação da função inspiratória e da capacidade funcional. Tese (doutorado) UFMG Escola de Educação Física, Fisioterapia e Terapia Ocupacional. Orient: Raquel Brito. 2015.

NAVARRO, Kathleen M. et al. Wildland firefighter smoke exposure and risk of lung cancer and cardiovascular disease mortality. Environmental research, v. 173, p. 462-468, 2019.

NIEHS/DHHS. National Institute of Environmental Health Sciences/ National Institute of health. DEPARTAMENT HEALTH AND HUMAN SERVICE. Wildfire Response Orientation Protecting Yourself While Responding to Wildfires: Safety and Health Awareness for Responders to Wildfires. WORKER TRAINING PROGRAM 2014.

$\mathrm{NIOSH}$ [2019]. Evaluation of wildland fire fighters' exposures to asbestos during a prescribed burn. By Grant, MP. Cincinnati, OH: U.S. Department of Health and Human Services. National Institute for Occupational Safety and Health, Health Hazard Evaluation Report 2017-0076-3352,

NWCG, 6 Minutes for Safety. Smoke Exposure. Category: Firefighter Health FirstAid. Page Last Modified / Reviewed: Dec 2019.

NWCG. Guidance for Monitoring and Mitigating Exposure to Carbon Monoxide and Particulates at Incident Base Camps. National Wildfire Coordinating Group

OLIVEIRA ALVES, Nilmara et al. Biomass burning in the Amazon region causes DNA damage and cell death in human lung cells. Scientific reports, v. 7, n. 1, p. 10937, 2017.

OSHA. WILDLAND FIREFIGHTING FACE MASKS OR-OSHA 2993-33 (7/16). Oregon OSHA Standard and Technical Resources Section.

OUELLET, Nicky. What It's Like Fighting Fire in Libby's Asbestos Forest. Montana Public Radio July 25, 2018.

PARREIRA VF, França DC, Zampa CC, Fonseca MM, Tomich GM, Britto RR. Pressões respiratórias máximas: valores encontrados e preditos em indivíduos saudáveis. Rev Bras Fisioter. 2007; 11: 361-8.

PASTORE, Oswaldo de Almeida; IRAMINA, Wilson Siguemasa. A influência da temperatura na eficiência de filtros com carga eletrostática usados na proteção respiratória. Rev. bras. saúde ocup., São Paulo, v. 34, n.119, p. 28-39, Junho 2009.

PEIXOTO, Milena Simões et al. Oxidative stress, mutagenic effects, and cell death 
Revista Científica do Corpo de Bombeiros Militar de Pernambuco

Artigo Publicado no Vol.06 N.17 - Edição Jul a Dez 2020 - ISSN 2359-4829

Versão on-line disponível em: http://www.revistaflammae.com

induced by retene. Chemosphere, v. 231, p. 518-527, 2019.

PESSOA, Isabela Maria Braga Sclauser. Valores de referência para a força muscular respiratória: metodologia recomendada por diretrizes internacional e brasileira. Tese (doutorado) - Universidade Federal de Minas Gerais, Escola de Educação Física, Fisioterapia e Terapia Ocupacional. Orientadora: Verônica Parreira Co-orientador: Miguel Houri Neto. 2013.

RANZANI, Otavio T. et al. Association of Ambient and Household Air Pollution With Bone Mineral Content Among Adults in Peri-urban South India. JAMA Network

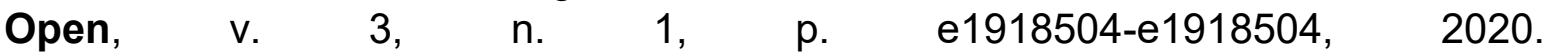
doi:10.1001/jamanetworkopen.2019.18504

REINHARDT, Timothy E.; OTTMAR, Roger D. Baseline measurements of smoke exposure among wildland firefighters. Journal of occupational and environmental hygiene, v. 1, n. 9, p. 593-606, 2004.

RIBEIRO, Helena; ASSUNÇÃO, João Vicente de. Efeitos das queimadas na saúde humana. Estudos avançados, v. 16, n. 44, p. 125-148, 2002.

RODRÍGUEZ-MARROYO, J. A. et al. Physical and thermal strain of firefighters according to the firefighting tactics used to suppress wildfires. Ergonomics, v. 54, n. 11, p. 1101-1108, 2011.

SBIHI, Hind; NICAS, Mark; RIDEOUT, Karen. Evidence Review: Using masks to protect public health during wildfire smoke events. BC Centre for Disease Control, Vancouver BC, 2014.

SOUZA, Paulo Roberto Macedo. Análise da exposição dos bombeiros ao monóxido de carbono liberado na fumaça dos incêndios florestais. 2011. Trabalho de Conclusão de Curso (Curso de Aperfeiçoamento de Oficiais) - Centro de Estudos de Política, Estratégia e Doutrina. Corpo de Bombeiros Militar do Distrito Federal, Brasília, 2011.

SWAN, R. International Association of Fire Firefighters. Consensus Standards for Wildland Firefighter Respiratory Protection. Roundtable: Respiratory Protection Use by Wildland Firefighters and Impacted Community Members. Sponsored Moldex-Metric,Inc. International Society for Respiratory Protection. 19th Internat Confer. Denver, Colorado Sept16-20,2018

TARÍN, Guillermo Soriano. Estudio de las demandas físicas y psíquicas requeridas para los trabajadores en la lucha contra incendios forestales. Repercusión en la salud y valoración en función de la edad. Federación de Industria y de los Trabajadores Agrarios de la Unión. Asociación Selvicultores de 
España. Fed. Agroalimentaria de Com. Obreras. 2013.

TORLONI, Maurício. Programa de proteção respiratória: recomendações, seleção e uso de respiradores/coordenador técnico, Maurício Torloni; equipe técnica, Antonio Vieira, José e Aquino, Sílvia Nicolai e Eduardo Algranti. - 4. ed.SãoPaulo: Fundacentro, 2016.

UCLA LOSH. WORKER PROTECTION FROM WILDFIRE SMOKE. Emergency Cal/OSHA Standard 2019. UCLA Labor Occupational Safety and Health Program (LOSH) under a grant from the National Institute for Environmental Health Sciences (NIEHS) Worker Training Program (Grant no. 3U45ES006173), October 2019.

URBANSKI, Shawn P.; HAO, Wei Min; BAKER, Stephen. Chemical composition of wildland fire emissions. Developments in environmental science, v. 8, p. 79-107, 2008.

YOUSSOUF, Hassani et al. "Non-accidental health impacts of wildfire smoke." International journal of environmental research and public health vol. 11,11 11772-804. 14 Nov. 2014.

WU, X. et al. Exposure to air pollution and COVID-19 mortality in the United States: A nationwide cross-sectional study. medRxiv. preprint doi: https://doi.org/10.1101/2020.04.05.20054502. this version posted April 27, 2020. 